\title{
O perskim oku i o tym, co naprawdę jest perskie w polskich konstrukcjach frazeologicznych
}

Słowa kluczowe: perskie oko, perski proszek, frazeologizmy, homofony.

doi: http://dx.doi.org/10.31286/JP.101.1.5

Okazja to perskie oko losu (Józef Bułatowicz)

90 lat temu prof. Stanisław Szober w książce Życie wyrazów po raz pierwszy objaśnił pochodzenie zwrotu perskie oko, wskazując, że jest to zapożyczenie semantyczne z francuskiego, a jego podstawą jest l'oeil perçant 'przenikliwe oko' (Szober 1929: 31-32). W odpowiedzi slawista Józef Birkenmajer opublikował na łamach „Języka Polskiego” artykuł, w którym dowodził krakowskiego rodowodu tego popularnego zwrotu, łącząc go - dość karkołomnie - z rysunkiem Persa na etykiecie popularnego wówczas proszku owadobójczego Zacherlin (Birkenmajer 1929). Tekst wywołał ożywioną dyskusję, do której na łamach „Języka Polskiego” włączyli się romanista Józef Morawski (1930) oraz slawista Henryk Ułaszyn (1929, 1930), a także komentujący: redaktor naczelny pisma Kazimierz Nitsch (1929a, b), Maria Dłuska (1929) i Mieczysław Broniatowski (1929) ${ }^{1}$.

Do nierozstrzygniętego tematu perskiego oka postanowiłam więc powrócić po latach, sama bowiem zawsze zastanawiałam się nad jego pochodzeniem. Wyrażenie to znane mi jest od dziecka; w mojej rodzinie tak mówiono na mrugające oko w starym odbiorniku radiowym. Podobno dawniej nazywano też tak szklaną protezę oka, która odbijając światło, dawała efekt celowego mrugania. Perskie, mrugające oko, a może szklane... czy aby na pewno ma ono jakikolwiek związek z Persją? Co w polszczyźnie mamy „perskiego” i czy rzeczywiście to, co mamy, jest perskie? ${ }^{2}$

W języku polskim przymiotnik perski/persyjański odnotowano po raz pierwszy w XVI wieku, kiedy Polska nawiązała polityczne i handlowe kontakty z Persją. W sPXVI przymiotnik perski odsyła do hasła śliwa (Prunus persica (L.) Batsch) 'brzoskwinia zwyczajna', cf. śliwa perska (SPXVI

\footnotetext{
* kinga.paraskiewicz@uj.edu.pl; ORCID: 0ooo-0oo3-2661-031X

1 Ożywiona dyskusja pewnie trwałaby nadal, gdyby nie prof. Nitsch, który ją zakończył. Zob. list K. Nitscha do H. Ułaszyna z 6 II 1930: „Co do perskiego oka, muszę być konsekwentnym. Na s. 178 «zamknąłem dyskusję», nie mogę więc pomieścić uwag powtarzających rzeczy już przez Pana samego podane” (Listy K. Nitscha...: 298).

2 W tym miejscu należy wspomnieć artykuł Jadwigi Waniakowej poświęcony nazwom „perskich” roślin w języku polskim: Waniakowa 2006: 207-214.
} 
XXIII: 391) oraz występuje pod hasłem bułat 'miecz perski zakrzywiony, szabla turecka z szeroką głownią, zrobiona z takiej stali; tarcza' (tamże): 1564: Acinaces 'miecz Perski álbo szabla Turecka, Bułát quidam dici volunt' (Mączyński 1564: 2c/47; Stachowski 2014: 93). W XVIII wieku, jak podaje ESXVII, ustabilizowane połączenia wyrazowe z przymiotnikiem perski to:

- król perski: „Król perski, którego wy kozulbaskiem zowiecie, walecznych Medów, potężnych Babilonów i inszych, którzy o sobie siła trzymali, moc częstokroć skracał" (Synod Ministrów: 197-227);

- język perski: „język perski (pahlawi?)”: „Ięzyk ná Dworze Perski, u Pospolstwa Indyiski, u Uczonych Bráchmański” (o dworze mongolskim w Indiach) (Chmielowski 1746: 591);

- chodzić po persku: „Po Włosku chodzę /noszę się/ po Pérsku etc. [...] In duo vestitum Persicum [...] i. vestior Persicomore [...]” (Kn. 721) ${ }^{3}$.

W sFskor pod hasłem perski znajdujemy następujące związki: „1. perski kobierzec, pas; perskie tkaniny; perska makata; perskie wazy. 2. bez perski (gatunek lilaka, Syringa persica) ${ }^{4}$. 3. karakuły perskie (barany, futro o gęstym, silnie skręconym włosie, barwy zwykle czarnej). 4. perski proszek (dawniejszy środek owadobójczy). 5. pszenica perska (gatunek pszenicy)" (sFskor I: 659). Zaś pod hasłem oko podano związek frazeologiczny: „robić, zrobić, puszczać perskie oko do kogo (spoglądać zalotnie, filuternie na kogo): Antek zrobił do niej perskie oko (Brzoza, Dzieci 203)" (sFskor I: 592).

\section{Perski kobierzec/dywan, pas, tkanina}

W istocie perskie kobierce i tkaniny wywodzą się z Persji i stamtąd były sprowadzane już od XVII wieku na zamówienie polskich królów i magnatów ${ }^{6}$. Były i są nadal tak popularne, że dziś sam wyraz pers używany jest potocznie w dwóch znaczeniach dywanu lub tkaniny (oraz kota ${ }^{7}$ ): „pers m. IV, Ms. persie. 1. pot. 'dywan perski’: Polskie persy rodem z... Mazur [...] pięknością nie ustępują słynnym "persom». Są równe puszyste, równie miękkie, o finezyjnych wzorach i subtelnych barwach. Exp. 108, 1958. 2. przestarz. 'cienka tkanina płócienna, kolorowa w kwiaty': Kaftan modry, którego jeden rękaw naszyty były wielką łatą z kwiecistego persu i fartuch siwy z domowej przędzy. KOnOPN. Now. II, 157. Pamiętam, matka moja kupiła jakiś perkal na suknię, nazywany persem i płaciła do dwadzieścia złotych za łokieć. Filarec. 216. // swil” (sJPDor). Por.

\footnotetext{
3 Hasło: perski, [w:] Elektroniczny słownik języka polskiego XVII i XVIII wieku (online: https://sxvii.pl/drukuj.php?strona= haslo\&id_hasla=16706\&forma=PERSKI).

4 Roślina znana w Europie od XVI w. W języku polskim z francuskiego lilas de Perse, por. niem. persischer Flieder. Zob. Waniakowa 2006: 209.

$5 \mathrm{Z}$ niemieckiego persischer Weizen.

6 Najbardziej znanym kupcem był Ormianin Sefer Muratowicz, który od 1596 roku towarzyszył poselstwom osmańskim do Polski. W latach 1601-1602 jako wysłannik dyplomatyczny króla Zygmunta III Wazy przebywał na dworze szacha Abbasa I, gdzie zamówił i nadzorował wykonanie namiotu, szabel, dywanów i tkanin do ozdobienia warszawskiej rezydencji królewskiej. Zob. Relacya Sefera Muratowicza Ormianina, posłanego króla Jmci do Persyi, z która wróciwszy się stamtąd podał na piśmie w te słowa..., [w:] Walaszek A. (red.) 1980.

7 „pers - m. IV 1. Pers - członek jednego z plemion perskich; 2. pot. a) dywan perski, b) kot perski” (PSJP PWN: 654). „Wyrazy pers i syjam/sjam/sjama stanowią jednowyrazowe, powstałe drogą uniwerbizacji odpowiedniki połączeń wyrazowych: kot perski, kot syjamski" (Obara 2003: 153).
} 
"pers - materja cienka do batystu podobna, kolorowa, w kwiatki” (sIJPArct); „tkanina cienka [...] Sł. wil." < fr. perse 'płótno kolorowe' (SW IV: 117). Podobnie angielskie Persian „a thin soft silk formerly used especially for linings" ${ }^{\prime}$. Mieliśmy też dawniej swoje persjarnie, czyli fabryki persjarskie (= fabryki pasów słuckich): „najsławniejsza w narodzie fabryka pasów, czyli persjarnia w Słucku"; zaś perska robota oznaczała właśnie tkanie pasów (sW IV: 118).

W sw mamy też: persan 1. 'podstawa pod posąg', 2. 'podpora pod belkę w budynku w stylu perskim', 3. 'posąg męskiej postaci użyty za podporę’ < łac. persanus; persjana 'żaluzja' < fr. persienne; persjanka 'gatunek gruszy i jej owocu'; persyko 'wódka brzoskwiniowa' < wł. persico (sW IV: 118-119).

\section{Perski proszek (Pyrethrum)}

W sw znajdujemy taką definicję perskiego proszku: „Lepszy gatunek proszku dalmackiego używany do tępienia robactwa domowego [...]" (SW IV: 118). Także tylko z nazwy perski, bo jest wynalazkiem europejskim: „sproszkowane kwiatostany niektórych gatunków złocienia (Chrysanthemum); środek owadobójczy” (sJPDor); „[...] roztarte na proszek korzenie i kwiaty rośliny maruna różowa i cielista, rosnącej w Persji i na Kaukazie, służy do tępienia robactwa domowego"9 (sIjPArct). Złocień jest stosowany od stuleci na Bliskim Wschodzie jako środek owadobójczy i jako środek przeciw wszom. Perski proszek (ang. Persian powder) był sprzedawany na całym świecie pod marką Zacherlin przez austriackiego przemysłowca Johanna Zacherla, który go opatentował w roku $1884^{10}$.

Drwal na wyręby się wybiera/ I do swej żony tak powiada:/ „Z robactwem kłopot mam nie lada;/ Prusaki w kuchni, w szafach mole,/ Muchy aż roją się w rosole,/ Komary spać nie dają przy tym,/ Trzeba to raz wytępić flitem!/ Niech zaraz Stefek i Janeczka/ Po flit pojadą do miasteczka" [...] A żona drwala, z kubłem wody/ Stąpając śmiało między wrogi,/ Szoruje ściany i podłogi./ Janeczka porządkuje kuchnię,/ Raz po raz w kąty flitem dmuchnie,/ A Stefek chłopiec bohaterski -/ Do łóżek sypie proszek perski [...] (J. Brzechwa, Za króla Jelonka, 1950).

\section{Perskie oko}

Perskie oko pojawia się po raz pierwszy w słownikach języka polskiego na początku Xx wieku. "«Oko robić» a. «Oko perskie (do kogoś) robić» = zalotnie spoglądać, wabić, flirtować. Ust.

8 „Cienki miękki jedwab dawniej używany specjalnie na podszewki”. Hasło: Persian, [w:] Merriam-Webster.com Dictionary, Merriam-Webster (online: https://www.merriam-webster.com/dictionary/Persian, dostęp: 15 marca 2020).

9 Por. Waniakowa 2006: 210.

10 Suszone i zmielone koszyczki kwiatowe chryzantem wykorzystywano na Bliskim Wschodzie „[...] od dawna, by pozbyć się uprzykrzonych owadów. Podpatrzył to podczas podróży do Gruzji pewien przedsiębiorczy wiedeńczyk Johann Zacherl (1814-1888). Zaczął sprowadzać do Wiednia suszone kwiaty chryzantem i tu wyrabiać na skalę przemysłową niezwykle skuteczny preparat owadobójczy. Zbił na «Zacherlinie» - jak nazwał swój wynalazek - fortunę. Można go było nabyć w każdej drogerii i sklepie chemicznym w całej monarchii, a w kilka lat potem w całej Europie. Był bez wątpienia najbardziej popularnym preparatem, który, jak czytamy w licznych inseratach prasy krakowskiej, «zabija owady - jako to mole, pluskwy, karakony, szwaby, gąsienice, komary, muchy itd. [...]»” (Hejże na owady, „Dziennik Polski” 11.06.2011 (online: https://dziennikpolski24.pl/hajze-na-owady/ar/3013524)). 
z Warszawy” (sGPKarł III: 428); „Perski, pochodzący z Persji, właściwy Persji a. Persom; gwar., oko perskie robić = oczkować, patrzeć zalotnie, figlarnie; oko perskie z makagigą! = figa malowana! nie dostaniesz! nie zrobisz!” (SIJPArct); „Oko perskie robić = patrzeć zalotnie. Perskie oko! Perskie oko z makagigą! Perskie oko w majonezie! (= akurat, a właśnie!)” (sfarct: 73). Czy rzeczywiście jest ono perskie? W języku perskim wyraz czaszm 'oko' ma swoje specyficzne użycie: gdy Pers zgadza się, akceptuje jakąś propozycję, mówi: Czaszmetun bibalo 'niech pańskiego oka nie spotka nieszczęście’, względnie samo Czaszm 'Oko!', co znaczy: 'Tak jest!, tak zrobię!' (czasem towarzyszy temu gest położenia rąk na powiekach „mam to na oku”). Jest to jednak gest poważny, bez porozumiewawczego mrugania. Ponadto, mimo pewnych kontaktów handlowych z Persją, Persowie nie byli nam dobrze znani, przez co często mylono ich z innymi, bardziej znajomymi orientalnymi nacjami (jak Turcy, Tatarzy, Ormianie). Świadczyć może o tym tekst XIX-wiecznej piosenki ludowej z okolic Warszawy, gdzie Gruzinów utożsamiono z Persami: „Nie pójdę ja grabić siana, bo się boję Persyjana. Bo Persyjan siedzi w lipie i wystrzescył na mnie ślipie” (Kolberg 1963: 172). Jest to utrwalona przez Kolberga ludowa pieśń z okolic Raszyna, gdzie w latach 1840-1850 miał stacjonować pułk z Kaukazu Południowego. Fragment ten mógłby sugerować, że ów związek frazeologiczny wziął się właśnie z zalotnych spojrzeń rzucanych na okoliczne włościanki przez Persyjan (Gruzinów, Ormian?) siedzących w lipie.

Władysław Kopaliński w Słowniku mitów i tradycji kultury notuje następujące związki: 1. perskie oko 'zwrot pochodzący z Krakowa, znaczący figa z makiem, guzik, ani mi się śni, mów mi wuju, alem cię wystrychnął na dudka, gadaj do lampy, adiù Fruziù!'; 2. robić (puszczać, sypać) perskie oko 'spoglądać kokieteryjnie, figlarnie' (Kopaliński 1985: 784). Na krakowski rodowód tego zwrotu wskazuje także wspomniany na wstępie J. Birkenmajer, autor artykułu o perskim oku w „Języku Polskim”, podważający hipotezę S. Szobera, który zaliczył perskie oko do zapożyczeń semantycznych:

Takim zapożyczeniem jest również przymiotnik perski używany w wyrażeniu perskie oko w znaczeniu 'przenikliwy, wabiący, kokietujący'. Jest to przeszczepienie na grunt polski zmiany, jaka się dokonała na skutek szczególniejszych warunków w odpowiedniku francuskim tego wyrazu. Punktem wyjścia było tu wyrażenie francuskie l’œil perçant 'przenikliwe oko'. Wskutek głoskowej tożsamości wyraz perçant został w poczuciu językowem francuskiem pomieszany z wyrazem persan 'perski', a na tle tego pomieszania przymiotnikowi persan przypisano to nowe, a tak niezwykłe, znaczenie 'przenikliwy' [to ciekawe objaśnienie pochodzenia znaczeniowego zwrotu perskie oko usłyszałem po raz pierwszy od prof. T. Benniego w dyskusji na jednem z posiedzeń Tow. Nauk. Warsz.]. Znaczenie to wraz z całem wyrażeniem myśmy przyjęli z języka francuskiego, jest to więc również semantyczne zapożyczenie (Szober 1929: 32).

W odpowiedzi na to Birkenmajer objaśnia:

Profesorowie Benni i Szober są stałymi mieszkańcami Warszawy, gdzie wyrażenie perskie oko jest zgoła nowe, bo dopiero wprowadzone podczas wojny (zdaje się, że dzięki legjonistom). Wyrażenie to istotnie utarło się obecnie w Warszawie jako synonim 'przenikliwości' czy raczej 'kokieterji.' Stąd słyszy się tu wyrażenia zrobił do mnie perskie oko (dawniej mówiło się poprostu: 
robić oko lub oczkować), on ma prawdziwie perskie oko. Perskiem okiem nazwano i wesoły teatrzyk warszawski, a że nazwa była niezupełnie zrozumiała, dowód w tem, że wyparła ją bardziej zrozumiała, choć mniej śmieszna i groteskowa, bądź co bądź dźwiękowo podobna nazwa Morskiego Oka (Birkenmajer 1929: 124).

Teatrzyk, o którym wspomina autor, to warszawski kabaret Perskie Oko (1925-1927), następnie Nowe Perskie Oko (1927-1928), do którego teksty pisał między innymi Julian Tuwim i w którym ironiczne skecze stanowiły główny repertuar. Jego nazwa jednak wcale nie była niezrozumiała ${ }^{11}$ :

W 1925 roku Qui pro Quo opuściła nie tylko trójka wspomnianych aktorów, ale i Lawiński, Rentgen i Olsza, zakładając Perskie Oko. Nota bene, istnieje legenda związana z tą nazwą. Otóż mówi się, że Konrad Tom, wychodząc z gabinetu dyrektora, trzasnął drzwiami mówiąc: Nie chcą dać podwyżki, to pokażemy im perskie oko! ${ }^{12}$

Myślę, że powodem zmiany nazwy nie mógł być niezrozumiały zwrot, skoro znał go przecież Władysław S. Reymont, zupełnie z Krakowem niezwiązany:

Siedzą i wygadują jakby na teatrze - zaczęła wyrabiać przedrzeźniające miny. - Oui, madame! Non, monsieur! Tu śmieszek, tam perskie oko, ówdzie mach-mach wachlarzom, indziej buzie w ciup a czułe spojrzenie" (NKJP: W.S. Reymont, Rok 1794, 1911),

czy Jerzy Kossowski ze Lwowa:

Dureń! Perskie oko! - To pióro z ogona. - Ale to się nazywa pawie oko! - Tak, oko z ogona. Jędrek odczuł jakąś nieprzyzwoitość; nie wiedział jaką, ale się zaczerwienił (NKJP: J. Kossowski, Kłamca, 1928).

W tym miejscu należy wspomnieć, że w Warszawie w latach 1925-1928 ukazywał się także tygodnik artystyczno-literacki „Perskie Oko” ${ }^{13}$, którego okładkę zdobił rysunek mrugającego Persa.

\footnotetext{
11 „Kiedy Perskie Oko po trzeciej premierze znów miało wyprzedane bilety, Qui Pro Quo wypuściło premierę Grunt się nie przejmować. Od tego czasu, aż do lat trzydziestych trwała zażarta konkurencja, z której zwycięsko wychodziła przede wszystkim publiczność raczona kilka razy w tygodniu fajerwerkami humoru i szlagierami najtęższych umysłów kabaretowych. Półtora roku funkcjonowania teatru było pasmem sukcesów, które spowodowały kolejne tarcia. Tym razem spór wiedziono o własność nazwy Perskie Oko, tak że w listopadzie 1927 roku powstał teatr Nowe Perskie Oko, a od tego momentu dzieli nas już tylko kilka miesięcy do inauguracji Morskiego Oka - teatru legendy” (hasło „Perskie Oko”, [w:] Encyklopedia teatru polskiego (online: http://encyklopediateatru.pl/teatry-i-zespoly/2081/perskie-oko?fbclid=IwAR2uq4WnXkLFD-KxG 2jwvxvsyumxMne6lhdjWhouMıpbqvigJiydr8urBaU, dostęp: 15 marca 2020)).

12 Perskie oko Konrada Toma (online: https://ksiazki.wp.pl/polak-humoris-causa-6145574684448385g/4, dostęp: 15 marca 2020).

13 Redaktorem naczelnym tygodnika był Bolesław Miciński, a następnie Harold Strasmen. Od numeru 9 wydawcą była Spółka Wydawnicza „Perskie Oko”. Dwa zachowane egzemplarze dostępne są online na stronie Polona: https://polona.pl/.
} 


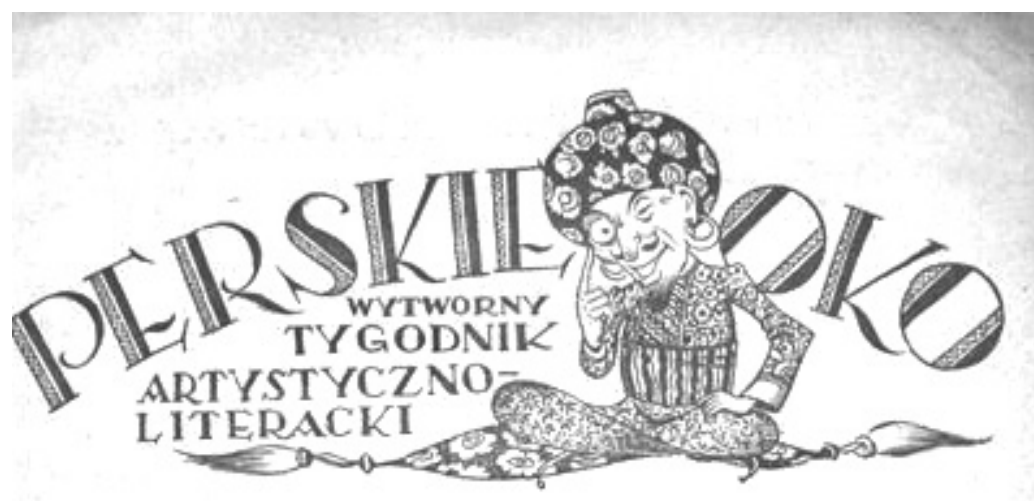

Rys. 1: Fragment okładki tygodnika „Perskie Oko” z 1926 r., nr 9 (online: https://polona.pl/item/perskie-okowytworny-tygodnik-artystyczno-literacki-1926-nr-9,NzQ4NzcwMjM/2/\#info:metadata - domena publiczna)

Birkenmajer stawia jednak hipotezę o krakowskim rodowodzie perskiego oka:

W każdym razie należy zaznaczyć, że zwrot ten - w Warszawie nowy i mało używany - jest rodem z Krakowa, gdzie był znany conajmniej od 30 lat i gdzie miał zawsze z goła in ne znaczenie. Perskie oko mianowicie znaczy w Krakowie tyle samo co 'figa $z$ makiem', 'guzik,' 'ani mi się śni, 'mów mi wuju', 'gadaj do lampy', 'baj baju', 'alem cię wystrychną na dudka', 'mąry mówi (pisze), głupi wierzy' itp. Słowem, zwrot ten bynajmniej nie mówi o jakiejś 'przenikliwości' ani 'kokieterji' - owszem jest to wyrażenie impertynenckie, oznaczające radość, że się kogoś okpiło, komuś coś zabrało, kogoś w pole wywiodło. Jako dowód przytoczę śpiewkę $\mathrm{z}$ «Krowoderskich zuchów», granych lat temu dwadzieścia w Krakowie:

Longwer z dziéwką sam na sam -

cym-cy-rym-cym-cym! -

wpada pani: „Ja ci dam!”

„Proszę pani, to mój brat!

Perskie oko, akurat!" (Birkenmajer 1929: 124-125)

Dalej dowodząc krakowskości zwrotu, autor przywołuje Tadeusza Boya-Żeleńskiego, który w Piosence wzruszajacej (Słówka. Zbiór wierszy i piosenek 1913) niby roztkliwia się nad cnotą, a po pierwszej i ostatniej strofie rysuje znak, który w przypisie objaśnia:

Autor uczuł potrzebę wzbogacenia pisowni polskiej nowym znakiem, który pozwala sobie nazwać terminem perskie oko. Znak ten pisarski, którego brak dawał się dotychczas dotkliwie uczuć, zwłaszcza w poezyi lirycznej, powinien stać się wkrótce równie niezbędnym jak dwukropek, myślnik, wykrzyknik itd. (Boy-Żeleński 1913: 161-162). 
64 | ARTYKUŁY I ROZPRAWY | J̨̨ZYK POLSKI | CI 1

Choć twej młodości jasny płomień

Iskrami bucha oszołomień

O Piękna ma,

Nie kusi mnie twych wdzięków wiosna

Kiedy promienna i radosna

Ku życiu drga...

Czy to jest przyjaźń idealna,

Czy też perwersya sexualna? -

Obłędne sny - ?

Ach, nie wiem, co się ze mną stało,

Lecz chciałbym pić przez WIECZNość całą

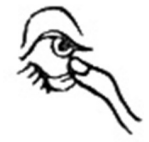

Twe drogie łzy,

Twe drogie łzy...

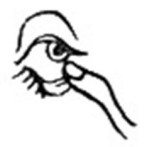

Birkenmajer idzie dalej w wyjaśnieniach:

Bo też u krakowian zwrot perskie oko łączy się zawsze z gestem, polegającym na tem, że końcem palca wskazującego pociąga się rożek szczeliny międzypowiekowej, tak iż szczelina ta przyjmuje układ skośny, przyczem często czerwone dno powieki na wierzch wychodzi [...] W tym geście też trzeba szukać genezy samego zwrotu. Sam ten gest, w plastyce swej bardzo zrozumiały, symbolizuje odmowę lub drwinę, podobnie jak figa z makiem - i zdaje się, że też miał źródło w jakiemś obscoenum, co zresztą Boy w rysunku swym dobrze uchwycił. Zaznaczę, że w niektórych gwarach i żargonach wyraz oko bywa istotnie dwuznaczny i miewa też znaczenie pornograficzne; kto wie, czy i robienie oka w znaczeniu erotycznem nie miało też kiedyś tego zabarwienia. Nadmienię, że i synonim perskiego oka (autentycznego, t.j. krakowskiego), mianowicie guzik, wyrósł podobnież z koprolalji, o czem zresztą pisał kiedyś ś.p. Mirosław Kryński (Birkenmajer 1929: 125).

W tym miejscu każdemu orientaliście skojarzyć się musi tzw. oko proroka, amulet w postaci niebieskiego szkiełka, mający chronić przed złym spojrzeniem (pamiątka obecnie masowo przywożona z Turcji przez turystów). Oko proroka, podobnie jak ręka Fatimy, ma za zadanie przechwycić owo spojrzenie, zanim wyrządzi ono krzywdę. Muzułmanie w wielu krajach wierzą bowiem w nazar, czyli urok rzucany świadomie lub nieświadomie przez spojrzenie. Ponoć szczególnie silne uroki potrafią rzucać osoby o niebieskich tęczówkach. Najpopularniejsze perskie amulety (czaszm-awiz) to oko ofiary (nazar-korbani) - zasuszone oko owcy zarżniętej na święto ofiarowania, błękitne koraliki, muszelki, ząb tygrysa, kopyta gazeli, wilcze pazury 
oraz niebieskie ubrania. Problem w tym, że nie wiemy, czy amulety te były znane w Polsce na początku XX wieku.

Jak z tego wynika, perskie oko nie ma z Persami nic wspólnego, choć Birkenmajer tak, dość karkołomnie, to tłumaczy:

Ale jakież skojarzenie takiego oka z Persem? Otóż Kraków przed 30 laty znał tylko jednego Persa, mianowicie etykietę na „proszku perskim” zwanym Zacherlin, a służącym do trucia owadów; był on w każdym składzie aptecznym i sklepie. Etykieta tego proszku, uwydatniana także na szyldach sklepowych, przedstawiała Persa w dużej czapie futrzanej, rozpylającego ów proszek i zerkającego chytrze z ukosa jednem, wydłużonem okiem w stronę nabywcy, niby celem stwierdzenia, jakie wrażenie wywołuje ów popis. Że takie spojrzenie perskie mogło się stać symbolem przebiegłości i chytrości, łatwo przypuścić. Pamiętam zresztą z lat dziecinnych spotykaną wówczas dość często - zabawę w takiego Persa (czasem Chińczyka), polegającą na tem, że zapomocą palców wskazujących przedłużało się lub nastawiało ukośnie szczelinę międzypowiekową (Birkenmajer 1929: 125-126).

Jednakże ów „Pers” wcale nie patrzył z ukosa, czego nie omieszkał wytknąć H. Ułaszyn: „Idę nawet dalej: odrzucam to tłumaczenie, gdyż nie mogę zrozumieć, co tu mógł «zawinić» ów rysunek Persa w czapce na owych pudełeczkach z perskim proszkiem: oka on tam nie robi” (Ułaszyn 1929: 174).

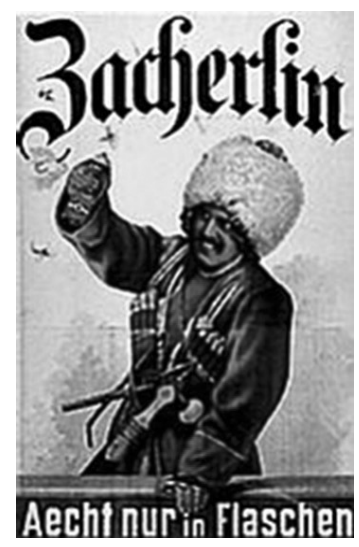

Rys. 2: Reklama proszku Zacherlin

(online: https://commons.wikimedia.org/wiki/File:Insecticide_zacherlin_190o.jpg - domena publiczna)

W dopisku pod tekstem Birkenmajera redaktor naczelny pisma K. Nitsch pisze:

Czy perskie oko pochodzi od „Persa” na zacherlinie, za to osobiście wolałbym nie ręczyć, ale że w Krakowie od dawna miało ono to znaczenie, o którym pisze p. Birkenmajer, to mogę potwierdzić. Przypomnę też słynną w swoim czasie, autentyczną czy zmyśloną telegraficzną 
odpowiedź, jaką fortepianowy mistrz dał prymitywnemu właścicielowi hotelu w Zakopanem na nieodpowiednią propozycję występu, brzmiała ona: „Morskie Oko, Dzikiewicz: Perskie oko Lalewicz”. Ale i w Warszawie znaczenie podane przez prof. Szobera wcale nie jest powszechne, bo oto na chybił trafił w Zakopanem zapytane trzy osoby (rodziny), niczem z sobą prócz warszawskiego pochodzenia nie związane, bez wahania określiły je jako kpiące, trywjalne, jedna nawet miała wyraźne poczucie zawartej w niem drastyczności. 'Kokieterja' napewno chyba jest tu drugorzędnym objawem złagodzenia (Nitsch 1929a: 126).

Na tym dyskusja się nie skończyła. W z. 6 „Języka Polskiego” z 1929 r. H. Ułaszyn w swoim tekście o perskim oku (Ułaszyn 1929) uznał hipotezę S. Szobera za prawdopodobną, choć powątpiewał w przejście perçant do persan. Na co odpowiedział romanista J. Morawski, który wytknął Szoberowi i cytującym go autorom, iż ulegli „mirażowi semantycznemu”, albowiem wyrażenie l’oil perçant nie jest francuskie, lecz raczej pseudofrancuskie: „Francuzi znają tylko regard perçant” (Morawski 1930: 81, 177). W odpowiedzi Ułaszyn przytoczył dowody na istnienie we francuskim powyższego zwrotu, choć powątpiewał, podobnie jak Nitsch, w mrugającego Persa z Zacherlina (Ułaszyn 1930) ${ }^{14}$.

Za hipotezą S. Szobera przemawia jednak świadectwo Juliana Tuwima, który choć w czasie trwania dyskusji o perskim oku na przełomie 1929 i 1930 roku głosu nie zabrał, po latach w opublikowanym zbiorze ciekawostek Pegaz dęba, czyli panopticum poetyckie (1950), w rozdziale Kalambur czyli karambol, przytacza zabawną anegdotę francuską opartą na całej serii homonimów, a kończącą się grą słów jednakowo po francusku wymawianych, lecz różnie pisanych (i co innego znaczących):

Burzę śmiechu wywołała kilkadziesiąt lat temu w parlamencie francuskim debata nad jakimś zagadnieniem polityki wschodniej. Tak się złożyło, że dwuznacznik padał za dwuznacznikiem: - C'est une chose de quelque importance que le siège d'Hérat (izba słyszy des rats i wybucha śmiechem).

- Le siège d'Hérat a excité les souris de la Chambre - wtrąca przewodniczący.

- Qu'en pense le shah (chat)? Nowy ryk śmiechu.

- Le shah les surveille: il a l'oil perçant (persan).

Historia ta nie została wymyślona przez Tuwima, znanego z tworzenia kalamburów, nie tylko w języku polskim. Zaczerpnął ją z francuskiego pisma satyrycznego „Les Guêpes” (Osy), z tekstu Alphonse’a Karra Travaux de la chambre des députés, discussions parlementaires. Question d'Orient ${ }^{15}$. A zatem ta francuska anegdota pochodzi z 1840 roku i mogła być znana polskim czytelnikom francuskiej prasy satyrycznej (Tuwim pamiętał ją bardzo dobrze, choć swój zbiór wydał dopiero w 1950 r.). Andrzej Pisowicz, który onegdaj przypomniał tę historyjkę na łamach „Przekroju”, dodaje: „Ciekawe, że dowcip ten we Francji uległ zapomnieniu,

14 Dyskusję tę opisano później w „Kwartalniku Historycznym” 1932, t. 46, cz. 2, z. 3-4, s. 179, a także we francuskim „Reuve des études slaves" 1930, nr 10, s. 138.

15 „M. HÉBERT: Qu'en pense le shah ? M. DE BELLEYME: Le shah les surveille; il a l'œil perçant» (Karr 1840: 12). 
natomiast przyjął się właśnie w Polsce i chyba tylko u nas nabrał znaczenia porozumiewawczego, kokieteryjnego zmrużenia jednego oka” (Pisowicz 1999: 36).

Jaki jest więc związek perskiego oka z zalotnym spojrzeniem, któremu towarzyszy błysk? Ten sam J. Tuwim w 1878 roku do wodewilu Feliksa Schobera Podróż po Warszawie układa kuplet zatytułowany Staroświecki optyk: „W kapeluszu, z wielkim kokiem/ I ze szkiełkiem od pan Pik/ Będziesz panna strzelać okiem/ I zadawać wielki szyk" (Schober 1878: 52; Tuwim 1958: 129). Irena Tuwim po latach wspomina:

Antosia pozostawała zawsze wierna kupletom z wodewilu Szobera, a ja za nią powtarzałam: W kapeluszu z wielkim kokiem I ze szkiełkiem od pan Pik Będzie panna strzelać okiem I zadawać grojse szyk. Szkiełko wyobrażałam sobie jako ozdobę podtrzymującą seledynową egretę na kapeluszu zalotnisi i śpiewałam „pampik”. Dopiero znacznie później dowiedziałam się, że szkiełko to było lorgnon, a pan Pik to znany optyk warszawski owych czasów (Tuwim 1956: 32).

A zatem zalotne panie „strzelały okiem” za pomocą szklanego szkiełka. Gdzie tu jednak Pers? Jedynym znanym Persem wówczas w Warszawie był bawiący tam przejazdem szach perski Naser ad-din Szah Kadżar ${ }^{16}$. Antoni Słonimski w Alfabecie wspomnień pisze:

Pierwszym mężem cioci Sobieszczańskiej był optyk Pik, którego Prus wspomina w Lalce. Plotka warszawska łączyła przyjazd szacha perskiego do Warszawy z romansem pięknej pani Pikowej. Mówiono, że: serce Pikowej pika, ale nie do Pika. Byli nawet tacy, którzy łączyli zamówienia i zakupy dokonywane przez szacha w firmie Pik z urodą mojej cioci (Słonimski 1989: 41).

Jak więc widzimy, poza kobiercem i tkaninami, które rzeczywiście sprowadzano z Persji lub wytwarzano w naszych persjarniach, pozostałe rzeczowniki występujące w polskich konstrukcjach frazeologicznych z przymiotnikiem perski mają z Persją niewiele wspólnego. Podobnie jest z perskim kotem, który wcześniej był znany w Europie jako kot angorski (ankarski) i którego sprowadzano do Europy także z Turcji i Damaszku (kot damasceński) ${ }^{17}$. Tak samo perski proszek był w istocie pochodzenia kaukaskiego (podobnie jak ów żołnierz pułku z Kaukazu zidentyfikowany jako Persjanin w pieśni ludowej zanotowanej przez Kolberga), karakuły wywodzą się z Azji Środkowej (miejscowość Karakul w Uzbekistanie), zaś perskie oko ${ }^{18}$ było francuskim kalamburem: l'oeil perçant 'oko bystre, przenikliwe' wymawiane tak samo jak l'oil persan 'perskie oko'.

16 Szach perski dwukrotnie był w Warszawie w latach 1873 i 1889.

17 Znane dawniej w Europie nazwy kota perskiego to: angorski, damasceński, szirazki, indyjski etc., co może świadczyć o tym, że owe przymiotniki nie odnoszą się do samego geograficznego pochodzenia tej rasy, ale zostały nadane dla podkreślenia prestiżu i egzotycznego charakteru zwierzęcia sprowadzanego z różnych regionów Bliskiego Wschodu na dwory europejskie (Digard 2005).

18 Choć Konstanty Rdułtowski, polski wygnaniec, który znalazł się w czasie wojny w Iranie, gotów jest przyjąć tezę o perskim mruganiu: „Jakoby Brückner uważa, że nasze określenie perskie oko pochodzi od francuskiego perçant - co znaczy przenikliwe, a nie ma nic wspólnego z Persją. A jednak... kobiety perskie nie tylko mają na ogół ładne czarne oczy, ale też świetnie robią autentyczne perskie oko spod jasnej zasłony, którą się zakrywają od czubka głowy aż do kolan" (Rdułtowski 1996: 148). 
Bibliografia

Birkenmajer J. 1929: O perskiem oku, „Język Polski” XIV, z. 4, s. 124-126.

Boy-Żeleński T. 1913: Słówka. Zbiór wierszy i piosenek, nakładem Księgarni Polskiej B. Połonieckiego, Lwów-Warszawa.

Broniatowski M. 1929: Dopisek do artykułu H. Ułaszyna „Perskie oko”, „Język Polski” XIV, z. 6, s. 177.

Brzechwa J. 1950: Za króla Jelonka, Wydawnictwo E. Kuthana, Warszawa-Kraków.

Chmielowski J.B. 1746: Nowe Ateny albo Akademia wszelkiey scyjencyi pełna (...), cz. II, Lwów 1746, s. 591.

Digard J-P. 2005: Persian cat, [w:] E. Yarshater (red.), Encyclopaedia Iranica (online: http://www.iranicaonline.org/articles/ cat-ii-persian-cat, dostęp: 15 marca 2020).

Dłuska M. 1929: Dopisek do artykułu H. Ułaszyna „Perskie oko”, „Język Polski” XIV, z. 6, s. 176-177.

ESXVII: Elektroniczny słownik języka polskiego XVII i XVIII wieku, red. W. Gruszczyński (online: https://sxvii.pl/, dostęp: 15 marca 2020).

Hejże na owady, „Dziennik Polski” 11.06.2011 (online: https://dziennikpolski24.pl/hajze-na-owady/ar/3013524; dostęp: 15 marca 2020).

Karr A. 1840 : «Les Guêpes», Février, t. 3, [s.n.], Paris, s. 12.

Kolberg O. 1963: Mazowsze, cz. 2, Polskie Towarzystwo Muzyczne, Ludowa Spółdzielnia Wydawnicza, Wrocław-KrakówWarszawa.

Kopaliński W. 1985: Słownik mitów i tradycji kultury, Państwowy Instytut Wydawniczy, Kraków.

Listy Kazimierza Nitscha do Henryka Ułaszyna (1905-1955), [w:] A. Czelakowska, M. Skarżyński (red.), Materiały do dziejów polskiego językoznawstwa, Kraków 2011, s. 203-326.

Mączyński J. 1564: Lexicon Latino-Polonicum ex optimis Latinae linguae scriptoribus concinnatum, Ioanne Mączinsky Equite Polono Interprete, Regiomonti Borussiae [przedruk w: „Slavistische Forschungen” 14, R. Olesch (oprac.), Köln-Wien 1973].

Morawski J. 1930: Stary pryk, „Język Polski” XV, z. 3, s. 81-83.

Nitsch K. 1929a: Dopisek do artykułu J. Birkenmajera „O perskiem oku”, „Język Polski” XIV, z. 4, s. 126.

Nitsch K. 1929b: Dopisek do artykułu H. Ułaszyna „Perskie oko”, „Język Polski” XIV, z. 6, s. 177-178.

NKJP: Narodowy Korpus Języka Polskiego (online: www.nkjp, dostęp: 15 marca 2020).

Obara J. 2003: Zapelatywizowane nazwy własne i ich formy pochodne w leksyce socjolektalnej, „Rozprawy Komisji Językowej Wrocławskiego Towarzystwa Naukowego", nr 29, s. 147-156.

Pisowicz A. 1999: O perskim oku [Listy do Redakcji], „Przekrój”, nr 48 (2841), s. 36.

PSJP PWN: Popularny słownik języka polskiego PWN, red. E. Sobol, Wydawnictwo Naukowe PWN, Warszawa 2001.

Rdułtowski K. 1996: Notatki z wygnania, posł. i przyp. S. Ciesielski, Polskie Towarzystwo Ludoznawcze, Urząd ds. Kombatantów i Osób Represjonowanych, Wrocław-Warszawa.

Schober F. 1878: Podróż po Warszawie. Operetka komiczna w 7 obrazach, [s.n.], Warszawa.

SFArct: M. Arcta słownik frazeologiczny: poradnik dla piszacych, M. Arct, H. Galle, A. Krasnowolski (red.), III wyd., Wydawnictwo M. Arcta, Warszawa 1928.

SFskor: S. Skorupka, Słownik frazeologiczny języka polskiego, Wiedza Powszechna, Warszawa 1989.

SGPKarł: J. Karłowicz, Słownik gwar polskich, t. 3, Akademia Umiejętności, Kraków 1903.

SIJPArct: M. Arcta słownik ilustrowany języka polskiego, Wydawnictwo M. Arcta, Warszawa 1916.

SJPDor: Słownik języka polskiego, red. W. Doroszewski, Państwowe Wydawnictwo Naukowe, Warszawa 1958-1969 (online: https://sjp.pwn.pl/doroszewski/perski;5471062.html; dostęp: 15 marca 2020).

Słonimski A. 1989: Alfabet wspomnień, wyd. 2, Państwowy Instytut Wydawniczy, Warszawa.

SPXVI: Słownik polszczyzny XVI wieku, red. R. Mayenowa, t. 23, Wydawnictwo Instytutu Badań Literackich, Warszawa 1995. Stachowski S. 2014: Słownik historyczno-etymologiczny turcyzmów w języku polskim, Księgarnia Akademicka, Kraków.

sw: Słownik języka polskiego, red. J. Karłowicz, A. Kryński, W. Niedźwiedzki, t. 4, nakładem prenumeratorów i Kasy im. Mianowskiego, Warszawa 1908 (Słownik warszawski).

Synod Ministrów... 1611, [w:] Z. Nowak, Kontrreformacyjna satyra obyczajowa w Polsce XVII wieku, Gdańsk 1968, s. 197-227. Szober S. 1929: Życie wyrazów, t. 1: Powstawanie wyrazów (nowotwory swojskie i zapożyczenia), Gebethner i Wolff, Kraków [i in.].

Tuwim I. 1956: Łódzkie pory roku, Wydawnictwo Literackie, Kraków.

Tuwim J. 1950: Pegaz dęba, czyli panopticum poetyckie, Wydawnictwo „Czytelnik”, Warszawa. 
Tuwim J. 1958: Cicer cum Caule, czyli groch z kapustą; panopticum i archiwum kultury, t. 1, Wydawnictwo „Czytelnik”, Warszawa.

Ułaszyn H. 1929: Perskie oko, „Język Polski” xIV, z. 6, s. 173-176.

Ułaszyn H. 1930: Dokoła perskiego oka, „Język Polski” XV, z. 4, s. 123-124.

Walaszek A. (red.) 1980, Trzy relacje z polskich podróży na Wschód muzułmański w pierwszej połowie XVII wieku, Wydawnictwo Literackie, Kraków, s. 35-47.

Waniakowa J. 2006: Bunch of Persian plants, [w:] A. Krasnowolska, K. Maciuszak, B. Mękarska (red.), In the Orient where the gracious light... Satura Orientalis in Honorem Andrzej Pisowicz, Księgarnia Akademicka, Kraków, s. $207-214$.

Summary

\section{On perskie oko ('Persian eye') and on what is really Persian in Polish phrasemes}

Keywords: perskie oko ('Persian eye'), perski proszek ('Persian powder'), idiomatic expressions, homophones.

The subject of the article are certain idiomatic expressions constructed with the adjective perski ('Persian') in Polish: perskie oko ('Persian eye'), perski dywan ('Persian carpet'), perski proszek ('Persian powder') etc. Moreover, the author attempts to answer the question: What do we have that is really Persian in Polish? Are these phrases really related to Persia or Persians, or are they just a word game (homophones)? So far the origin of the most popular one, i.e. perskie oko ('Persian eye') has not been established even though a lively discussion on this subject was held on the pages of the Jezzyk Polski 90 years ago. It was started by Stanisław Szober who in his book Życie wyrazów, explained the origin of the phrase perskie oko for the first time, indicating that it is a semantic borrowing from French, and its basis is l'oil perçant 'piercing eye.' In response, Józef Birkenmajer claimed this popular phrase comes from Krakow, relating it - quite incredibly to a Persian man on the label of the popular Zacherlin insecticide powder called perski proszek ('Persian powder'). It turns out that the source of this expression was a French anecdote by Alphonse Karr from the late nineteenth century based precisely on the word game. 